\title{
Digestibility, Milk Production, and Udder Health of Etawah Goat Fed with Fermented Coffee Husk
}

\author{
I. Badarina ${ }^{\mathrm{a}, *}$, D. Evvyernie ${ }^{\mathrm{b}}$, T. Toharmat ${ }^{\mathrm{b}}$, E. N. Herliyana ${ }^{\mathrm{c}}$, \& L. K. Darusman ${ }^{\mathrm{d}}$ \\ aGraduate School of Animal Nutrition and Feed Science, Bogor Agricultural University \\ ${ }^{b}$ Department of Nutrition and Feed Technology, Faculty of Animal Science, Bogor Agricultural University \\ 'Department of Sylviculture, Faculty of Forestry, Bogor Agricultural University \\ ${ }^{d}$ Department of Chemistry, Faculty of Mathematics and Natural Science, Bogor Agricultural University \\ Kampus IPB Darmaga, Bogor 16680, Indonesia \\ (Received 20-08-2014; Reviewed 17-10-2014; Accepted 05-12-2014)
}

\begin{abstract}
This study was carried out to assess the utilization of coffee husk fermented by Pleurotus ostreatus as feed supplement by measuring the digestibility, the milk production and udder health of Etawah goat suffered from subclinical mastitis $(+1)$. There were three experimental diets consisted of T0 (control diet/basal diet without fermented coffee husk), T1 (basal diet with $6 \%$ fermented coffee husk) and T2 (basal diet with $6 \%$ fermented coffee husk soaked in crude palm oil for an hour before using). Basal diet consisted of Elephant grass $(60 \%)$ and concentrate $(40 \%)$. The results showed that supplementation of lactating Etawah does with fermented coffee husk did not affect the palatability of the diets, but increased the protein and crude fiber consumption $(P<0.05)$. There was no significant effect on nutrient digestibility and milk production while milk composition (protein, fat, total solid) increased in supplemented groups $(\mathrm{P}<0.05)$. The persistency of milk production and the somatic cells count was not different. There was an improvement of somatic cells count on supplemented groups. In conclusion, fermented coffee husk could be used as feed supplement without any negative effects on digestibility and milk production. The positive effects to udder health could be expected from including fermented coffee husk in diets.
\end{abstract}

Key words: coffee husk, Etawah, fermented, performance, supplement

\section{ABSTRAK}

Penelitian ini bertujuan untuk mengevaluasi pemanfaatan kulit buah kopi yang telah difermentasi dengan Pleurotus ostreatus sebagai pakan suplemen dengan mengukur kecernaan, produksi susu, dan kesehatan ambing kambing Etawah yang menderita mastitis subklinis $(+1)$. Terdapat tiga perlakuan ransum, yaitu T0 (ransum basal tanpa suplementasi kulit buah kopi fermentasi), T1 (ransum basal dengan suplementasi kulit buah kopi fermentasi sebanyak $6 \%$ ), dan T2 (ransum basal dengan suplementasi $6 \%$ kulit buah kopi fermentasi yang telah direndam dalam CPO sebelum digunakan). Ransum basal tersusun atas rumput gajah $(60 \%)$ dan konsentrat $(40 \%)$. Hasil penelitian menunjukkan bahwa suplementasi kulit buah kopi fermentasi tidak menurunkan palatibilitas ransum, tetapi meningkatkan konsumsi protein dan serat kasar $(\mathrm{P}<0.05)$. Tidak terdapat pengaruh yang nyata pada kecernaan nutrisi dan produksi susu sementara komposisi susu (protein, lemak, total padatan) meningkat pada kelompok yang disuplementasi $(P<0.05)$. Persistensi produksi susu dan jumlah sel-sel somatik tidak berbeda nyata. Terdapat perbaikan dalam jumlah sel-sel somatik pada kelompok yang disuplementasi. Disimpulkan bahwa kulit buah kopi yang telah difermentasi dapat digunakan sebagai pakan suplemen tanpa menimbulkan pengaruh negatif pada kecernaan dan produksi susu. Pengaruh positif pada kesehatan ambing dapat diharapkan dari suplementasi kulit buah kopi fermentasi dalam ransum.

Kata kunci: kulit buah kopi, fermentasi, Etawah, penampilan, suplemen

*Corresponding author:

E-mail: irmabadarina@gmail.com 


\section{INTRODUCTION}

Application of agricultural by-products as feed resources is one of strategy to reduce the environmental problem and create local feed resources. One of the agricultural by-products that is available in large quantities in Indonesia is coffee husk. Coffee is one of the agricultural crops with significant economic contribution in Indonesia.

Coffee husk can be converted into several added values products including as a feedstuff. Coffee husks can be used as a feed especially as a source of fiber. Coffee husks consist of $15.0 \%$ moisture, $5.4 \%$ ash, $7.0 \%$ protein, $0.3 \%$ lipids, $33.65 \%$ crude fiber and $38.65 \%$ nitrogen free extract (Gouvea et al., 2009). Lignin, caffeine and polyphenols were some anti-nutrients materials found in coffee husk (Fan et al., 2006). The pre-treatment of coffee husk before being used as a feedstuff must be done to overcome the obstacles and improve its utilization.

Fermentation by using Pleurotus ostreatus is one of the methods to improve the nutritive value of crop residues. $P$. ostreatus or oyster mushroom can be cultivated on wide range of lignocellulotic substrates such as wheat straw and sugar cane bagasse (Fazaeli et al., 2004; Okano et al., 2007). P. ostreatus produces ligninolytic extracellular enzymes such as laccase, lignin peroxidase and Mn peroxidase (Periasamy \& Natarajan, 2004). Application of bioconversion in lignocellulose residues is the efficient way because of low cost and positive environmental benefits.

Besides as primary decomposer of lignocellulotic materials, mushrooms have also been used as food supplement because of their medicinal properties. $P$. ostreatus possesses a number of biologically active compounds that function as health-enhancers, has a potency to cure diseases and biological response modifiers (Wong et al., 2011: Patel et al., 2012; Novak \& Vetvicka, 2009). One of bioactive substances responsible for biological action is $\beta$-glucan, a part of polysaccharides that form an integral part of fungal cell wall (Chen \& Seviour, 2007). The actions of $\beta$ glucan in treating and preventing diseases are through immunomodulator effects. $\beta$ glucan enters the proximal small intestine and then is captured by the macrophages. $\beta$ glucans are internalized and fragmented into smaller sizes and are carried to bone marrow and endothelial reticular system. The small $\beta$ glucans fragments are then released by macrophages and taken up by circulating granulocytes, monocytes and dendritic cells. The immune response will then be elicited (Chan et al., 2009).

Subclinical mastitis is one of the most important diseases in dairy farm including in Etawah dairy goat. Mastitis is an inflammation of mammary gland parenchyma which is caused by bacteria and its toxin. This disease is not only the animal welfare problem but also a food safety problem and the biggest economy problem to the farmer. Mastitis decreases milk production increases medical cost and causes the earlier culling of the animal (Sharif et al., 2009). The antibiotic usage is one of the methods often used to treat mastitis. However, due to the growing concern of antibiotic residues and resistance, the use of antibiotic was banned. A potential alternative to antibiotic is natural or traditional medicine. Mushrooms have been exploited for the treatment of many diseases such as $P$. ostreatus.

Since coffee husks are rich in the organic substances and nutrients, these materials are appropriate as substrates for mushroom cultivation. Solid state fermentation (cultivation) was made to use this residue and there was an increasing in its nutritive value (Murthy \& Mannomani, 2008). Even though some studies for solid state fermentation for coffee husk were confirmed, no study was examined with regard to its supplementation in ruminant diets in particular to the biological properties of fermented coffee husks to animal performance.

The fermented coffee husks are full growth of mycelium in the coffee husk substrate (vegetative phase). It is hoped that cultivation of coffee husk with P. ostretus not only does enhance the nutrient content but also contains a biological active compound that improves the health of animals consuming it. This study was carried out to assess the applicability of coffee husk cultivated with $P$. ostreatus as a feed supplement by measuring the digestibility and the milk production of Etawah dairy goat suffering from subclinical mastitis.

\section{MATERIALS AND METHODS}

\section{Coffee Husk Cultivation with Pleurotus ostreatus}

Coffee husks were solar dried until its moisture content range was $10 \%-15 \%$. The cultivation method and the composition of solid substrate were conducted according to Herliyana et al. (2008) with slight modification. The substrate consisted of $82.5 \%$ of coffee husks, $15 \%$ rice bran, $1.5 \%$ gips, and $1.0 \% \mathrm{CaCO}_{3}$. The clean water was added into the substrate as much as $65 \%-70 \%$ $(\mathrm{v} / \mathrm{w})$. All the components were composted for $24 \mathrm{~h}$ and then was placed into polypropylene bags as much as 400 $\mathrm{g}$ per bag. The bag logs were sterilized on $121{ }^{\circ} \mathrm{C}$ for 30 min. After cooling, each bag was inoculated aseptically with $P$. ostreatus grain spawn and incubated in an incubating room at $23-24{ }^{\circ} \mathrm{C}$ and approximately $80 \%$ relative humidity. Each spawned bag was closed with a small sterile cotton plug inserted in the middle of its opening. All bags were placed in incubating room and after $60 \mathrm{~d}$ the substrates were fully colonized and the primordial started to appear. The fully colonized substrates were solar dried and ready to use as feed. The nutrient content of coffee husk substrate is presented in Table 1.

\section{Chemical Composition Analysis of Diets}

$\beta$-glucan contents of fermented coffee husk substrates were determined by acidic and enzymatic hydrolysis using mushroom and yeast $\beta$-glucan assay according to the manufactures protocol (Megazyme, Wicklow, Ireland).

Moisture content, crude protein, ether extract, ash content and crude fiber of the diet were determined by proximate method. Celluloses, hemicelluloses, lignin, NDF and ADF were analyzed according to the method as described by Goering and Van Soest (1970). Tannin was determined by using Folin Ciocalteau (Harborne, 
Table 1. Nutrient contents of coffee husk substrate fermented by Pleurotus ostreatus (Dry matter basis)

\begin{tabular}{lcc}
\hline \multirow{2}{*}{ Nutrient component (\%) } & \multicolumn{2}{c}{ Coffee husk } \\
\cline { 2 - 3 } & $\begin{array}{c}\text { Without } \\
\text { fermentation }\end{array}$ & Fermented \\
\hline Organic Matter & 93.27 & 86.60 \\
Crude protein & 10.36 & 12.14 \\
Crude fiber & 39.43 & 46.83 \\
Ether extract & 0.97 & 1.67 \\
NDF & 95.18 & 79.08 \\
ADF & 87.18 & 74.08 \\
Hemicelluloses & 7.99 & 5.32 \\
Celluloses & 19.51 & 24.79 \\
Lignin & 65.42 & 45.04 \\
Tannin & 1.02 & 0.18 \\
Caffein & 1.39 & 0.82 \\
$\beta$-glucan (\%w/w) & 0.80 & 4.25 \\
Ca (\%) & 0.56 & 1.28 \\
P (\%) & 0.02 & 0.08 \\
Fe (\%) & 0.08 & 0.11 \\
Zn (ppm) & 14.00 & 12.00 \\
\hline
\end{tabular}

1989). Caffeine and mineral contents (Ca, P, Fe, and Zn) were determined according to AOAC procedure (2005).

\section{Animals and Treatments}

Twelve Etawah dairy goats were used in this experiment. The goats with the $2^{\text {nd }}$ to $3^{\text {rd }}$ lactation period and the mean of body weight of $40 \pm 5 \mathrm{~kg}$ were arranged in a randomized block design. All experimental goats suffered from subclinical mastitis with the score +1 based on California Mastitis Test (Shearer \& Harris, 2008).

There were three experimental diets with the criteria: $\mathrm{T} 0$ (control diet $=$ basal diet without fermented coffee husk supplementation), T1 (basal diet with $6 \%$ fermented coffee husk supplementation) and T2 (basal diet supplemented with $6 \%$ fermented coffee husk soaked for an hour in 3\% crude palm oil). The supplementation of $6 \%$ fermented coffee husk gave the best result from the preliminary in vitro digestibility research that was done by the authors. The aim of soaking in the palm oil is to protect the bioactive substances in fermented coffee husk from rumen degradation. Tabrizi et al. (2011) reported that fat (palm oil) could be used as a coating substance to reduce the speed of fermentation in the rumen.

Basal diet comprised mainly of cassava waste, coconut meal, soybean wastes meal, rice bran and crude palm oil. The formulation and chemical analyses of basal diet are presented in Table 2. Goats were fed twice daily in amounts adequate to ensure dry matter intake of $3.5 \%$ body weight per day. The diet was arranged to fulfill the nutrient for goat with crude protein 11\%-12\% and TDN 55\% (NRC, 2001). Feeding trial lasted for 45 d. Goats were milked every day at 07.00 and 17.00. The chemical composition of the experimental diets is presented in Table 3.

\section{Measurements of Feed Intake, Digestibility, and Milk Production}

Feed intake. Voluntary feed intake (VFI) for each animal was recorded individually on daily basis. Feed intake was the difference between amount offered and amount left. Dry matter intake (DMI) was estimated from VFI $x$ percentage of dry matter (DM).

Digestibility. Samples of all feed offered, feed left and feces were collected every day during the last week of the experimental period. As much as $10 \%$ from the total samples (feed offered, feed left and feces) were collected for determining the nutrients by proximate analysis. Samples were analyzed for dry matter, organic matter, crude fiber, crude protein and ether extract.

Milk recording and composition. Daily milk production was recorded every day. A composite of milk samples

Table 2. Ingredients of concentrate and chemical composition of the diets

\begin{tabular}{lcc}
\hline \multicolumn{1}{c}{ Ingredient } & $(\%$ of DM) & \\
\hline Soybean wastes meal & 34.88 & \\
Rice bran & 23.26 & \\
Coconut wastes meal & 23.26 & \\
Cassava wastes & 11.63 & \\
Crude palm oil & 6.97 & \\
Total & 100.00 & \\
& Concentrate & Elephant \\
Chemical composition & diet & grass \\
& 85.05 & 21.00 \\
Dry matter (\%) & 10.38 & 10.60 \\
Ash (\%) & 15.33 & 9.60 \\
Crude protein (\%) & 30.94 & 32.70 \\
Crude fiber (\%) & 5.66 & 1.90 \\
Ether extract (\%) & 71.96 & 52.28 \\
Total digestible nutrient & &
\end{tabular}

Table 3. Chemical composition of experimental diets

\begin{tabular}{lrrr}
\hline Chemical composition & T0 & \multicolumn{1}{c}{ T1 } & \multicolumn{1}{c}{ T2 } \\
\hline Dry matter (\%) & 41.70 & 42.06 & 41.76 \\
Ash (\%) & 9.20 & 9.45 & 9.56 \\
Crude protein (\%) & 11.12 & 11.92 & 11.71 \\
Crude fiber (\%) & 30.65 & 33.69 & 32.46 \\
Ether extract (\%) & 3.09 & 2.53 & 2.81 \\
Total digestible nutrient (\%) & 55.28 & 54.91 & 54.70 \\
\hline
\end{tabular}

Note: T0 (control diet= basal diet without fermented coffee husk supplementation), T1 (basal diet with $6 \%$ fermented coffee husk supplementation), and T2 (basal diet supplemented with $6 \%$ fermented coffee husk soaked for an hour in 3\%crude palm oil). ${ }^{1} \mathrm{TDN}=\mathrm{To}-$ tal digestible nutrients; calculated by using the equation of NRC (2001). 
were collected twice daily at regular milking times (07:00 and 17:00). Milk samples were analyzed for fat, protein, total solid (TS) and solid-nonfat (SNF) at Veterinary Public Health Laboratory of Bogor Agricultural University.

\section{Data Analysis}

All statistical analyses of the data obtained were performed to analyze variances (Steel \& Torrie, 2003). Means among treatments were compared by Duncan Multiple Range Test (DMRT). Statistical differences were expressed at $\mathrm{P}<0.05$.

\section{RESULTS AND DISCUSSION}

\section{Feed Intake}

The result showed that the daily intake of dry matter $(\mathrm{DM})$, organic matter $(\mathrm{OM})$, ether extract (EE), and nitrogen free extract (NFE) were not affected by supplementation of fermented coffee husk (Table 4). This condition indicated that the supplementation of fermented coffee husk did not decrease the palatability of rations. The improved feed consumption in supplemented ration was possibly related to the improved nutrient quality of fermented coffee husk (Table 1). Badarina et al. (2013) reported that cultivation of coffee husk with P. ostreatus increased its protein and cellulose contents, and decreased its lignin, tannin and caffeine contents. This result was consistent with another study (Fazaeli et al., 2002), who reported that the application of rice straw treated with Pleurotus spp. mushroom in the ration did not influence the dry matter consumption of the ration.

The improved feed consumption in fermented product was probably related to the change in chemical composition or biodegradation of cell wall component of lignocellulose material during fermentation period so that the feeds were easily digested. Sanchez (2009) said that during biodegradation process the conversion of lignocellulose into a feedstuff, at least one of the three objectives must be reached i.e., the increased protein content, the enhancement of lignocellulose digestibility and the improved palatability of the dry product.
The crude protein and crude fiber consumptions in control (T0) group were the lowest $(\mathrm{P}<0.05)$ as compared to the other groups. Results obtained in this study revealed that supplementation of fermented coffee husk increased crude protein and crude fiber consumption $(\mathrm{P}<0.05)$. Supplementation of fermented coffee husk increased the nutrient quality of the rations especially crude protein and crude fiber (Table 3 ). The possible reason for the increased quality of ration was related to good quality of fermented coffee husk. This result indicated that bioconversion with $P$. ostreatus looked promising in increasing the nutritive value of coffee husk. The cultivation of mushroom upgraded the nutritionally poor residues into a protein-rich material for animal feed. The increased protein content of poor residues during the course of biodegradation was also reported by Parani \& Eyini (2012) who found that there was the protein enrichment in coffee pulp substrate after biodegradation with white rot fungi.

\section{Digestibility of the Diets}

The supplementation of fermented coffee husk in the diet did not affect the digestibility of nutrients (Table 5). The TDN contents were also statistically similar among the diets. The possible reason for this result was that mushroom in the cultivation improved the digestibility of the coffee husk so that supplementation of fermented coffee husk did not influence the nutrient digestibility of the basal diets.

The cultivation of coffee husk with $P$. ostreatus could breakdown the lignin and cellulotic linkage that facilitates the penetration of the celluloses produced by rumen microbes that finally improved the crude fiber digestion. This result is consistent with another study (Hassim et al., 2012) reporting that the fungal pre-treatment using white rot fungi increases the degradability of palm oil frond in the rumen. This improvement in degradability is contributed by the mushroom that degrades the lignin of palm oil fronds. The removal of lignin barrier causes, cellulose becomes easily accessible for bioconversion.

Table 4. Nutrients consumption of goat fed with experimental diets

\begin{tabular}{lrrrr}
\hline Nutrient components & \multicolumn{1}{c}{$\mathrm{T} 0$} & \multicolumn{1}{c}{$\mathrm{T} 1$} & $\mathrm{~T} 2$ & P value \\
\hline Dry matter $(\mathrm{kg} /$ day $)$ & $1.44 \pm 0.11$ & $1.48 \pm 0.04$ & $1.56 \pm 0.11$ & 0.14 \\
Dry matter (\% body weight) & $3.40 \pm 0.52$ & $3.95 \pm 0.74$ & $3.45 \pm 0.66$ & 0.14 \\
Dry matter $\left(\mathrm{g} / \mathrm{BW}^{0.75}\right)$ & $72.07 \pm 5.82$ & $91.69 \pm 14.99$ & $98.40 \pm 18.46$ & 0.14 \\
Organic Matter $\left(\mathrm{g} / \mathrm{BW}^{0.75}\right)$ & $64.18 \pm 5.03$ & $81.77 \pm 13.36$ & $87.29 \pm 16.09$ & 0.13 \\
Crude protein $\left(\mathrm{g} / \mathrm{BW}^{0.75}\right)$ & $8.50 \pm 0.65^{\mathrm{b}}$ & $11.54 \pm 1.88^{\mathrm{a}}$ & $12.02 \pm 2.14^{\mathrm{a}}$ & 0.05 \\
Crude Fiber $\left(\mathrm{g} / \mathrm{BW}^{0.75}\right)$ & $26.10 \pm 2.20^{\mathrm{b}}$ & $32.19 \pm 5.24^{\mathrm{ab}}$ & $36.26 \pm 6.76^{\mathrm{a}}$ & 0.05 \\
Ether extract $\left(\mathrm{g} / \mathrm{BW}^{0.75}\right)$ & $1.54 \pm 0.08$ & $1.69 \pm 0.29$ & $1.94 \pm 0.29$ & 0.32 \\
Nitrogen Free Extract $\left(\mathrm{g} / \mathrm{BW}^{0.75}\right)$ & $21.24 \pm 1.45$ & $28.22 \pm 4.64$ & $27.51 \pm 4.90$ & 0.15 \\
\hline
\end{tabular}

Note: Means in the same row with different superscripts differ significantly $(\mathrm{P}<0.05)$. T0 (control diet= basal diet without fermented coffee husk supplementation), T1 (basal diet with $6 \%$ fermented coffee husk supplementation), and T2 (basal diet supplemented with $6 \%$ fermented coffee husk soaked for an hour in $3 \%$ crude palm oil). 
Table 5. Nutrients digestibility and total digestible nutrient (TDN) of the experimental diets

\begin{tabular}{lcccc}
\hline \multicolumn{1}{c}{ Nutrient components } & T0 & T1 & T2 & P value \\
\hline Dry matter (\%) & $76.74 \pm 2.76$ & $75.67 \pm 1.52$ & $74.50 \pm 3.02$ & 0.57 \\
Organic matter (\%) & $78.15 \pm 3.29$ & $77.44 \pm 1.33$ & $76.26 \pm 2.87$ & 0.66 \\
Crude protein (\%) & $81.47 \pm 3.81$ & $80.50 \pm 0.75$ & $78.67 \pm 3.30$ & 0.53 \\
Crude fiber) & $79.04 \pm 6.74$ & $82.88 \pm 10.04$ & $76.97 \pm 3.00$ & 0.55 \\
Ether extract (\%) & $85.87 \pm 5.14$ & $84.07 \pm 0.91$ & $80.58 \pm 2.94$ & 0.11 \\
Nitrogen free extract (\%) & $82.04 \pm 3.31$ & $79.54 \pm 1.98$ & $78.81 \pm 3.30$ & 0.25 \\
Total digestible nutrient (\%) & $61.07 \pm 6.45$ & $67.33 \pm 4.05$ & $63.43 \pm 2.29$ & 0.29 \\
\hline
\end{tabular}

Note: Means in the same row with different superscripts differ significantly $(\mathrm{P}<0.05)$. T0 (control diet= basal diet without fermented coffee husk supplementation), T1 (basal diet with $6 \%$ fermented coffee husk supplementation), and T2 (basal diet supplemented with $6 \%$ fermented coffee husk soaked for an hour in $3 \%$ crude palm oil).

\section{Milk Production and Composition}

Table 6 shows the average milk yield and its composition. The results indicated no significant different in milk yield and fat corrected milk (FCM) among treatments. It means that supplementation of fermented coffee husk did not affect milk yield. A possible reason for the lack response in milk yield is because the feed intakes (DM and OM) among treatments were not different. The quantity and quality of milk production depend upon nutrition supply (Min et al., 2005).

The supplementation of fermented coffee husk had a significant effect on milk composition $(\mathrm{P}<0.05)$. The concentration of fat, protein and total solid increased in the supplemented group. This condition may be related to the milk production. The milk nutrients concentrations were higher in the lower milk production where milk was more concentrate (Table 4).

The persistency of milk production was not different among treatments. The persistency of $\mathrm{T} 1$ treatment was the highest $(91.39 \pm 12.31 \%)$ than T0 $(89.35 \pm 17.37 \%)$ and T2 $(79.62 \pm 25.41 \%)$. The supplementation of fermented coffee husk especially on T1 group can maintain the milk level production for a longer time period. This condition may be related to the better udder health on $\mathrm{T} 1$ group.

The udder's health was evaluated by determining the somatic cells count (SCC). Somatic cells are indicators of both resistance and susceptibility to mastitis and can be used to monitor the level or occurrence of subclinical mastitis in herds or individual cow (Sharif \& Muhammad, 2008; Sudarwanto \& Sudarnika, 2008). The somatic cells count were not significant different. However, there was a tendency that somatic cells count in T1 and T2 groups (supplemented groups) were lower than in T0. The percentage of SCC change was the lowest in $\mathrm{T} 1(-28.74 \%)$. This condition suggested that there was the improvement of udder health in the lactating Etawah goats supplemented with fermented coffee husk (T1 dan T2). The goats supplemented with fermented coffee husk in T1 group could be classified into no infection condition, while in $\mathrm{T} 2$ group, the lactating goat could be classified into minor pathogen (Sharma et al., 2011). This study indicated that fermented coffee husk can give the positive effect on animal health by decreasing somatic

Table 6. Milk production and milk composition of Etawah goat fed with experimental diets

\begin{tabular}{lcccc}
\hline & T0 & T1 & T2 & P value \\
\hline Milk production (kg/day) & $0.74 \pm 0.18$ & $0.55 \pm 0.12$ & $0.62 \pm 0.23$ & 0.33 \\
Fat corrected milk (kg/day) & $1.00 \pm 0.31$ & $0.75 \pm 0.21$ & $0.92 \pm 0.35$ & 0.18 \\
Milk composition (\%): & & & \\
$\quad$ Density & 1.027 & 1.027 & 1.026 & 0.77 \\
$\quad$ Fat & $6.10 \pm 0.28^{\mathrm{b}}$ & $6.40 \pm 0.55^{\mathrm{ab}}$ & $6.85 \pm 0.21^{\mathrm{a}}$ & 0.03 \\
$\quad$ Protein & $4.45 \pm 0.14^{\mathrm{b}}$ & $4.60 \pm 0.28^{\mathrm{ab}}$ & $4.83 \pm 0.10^{\mathrm{a}}$ & 0.03 \\
$\quad$ Total solid & $15.19 \pm 0.22^{\mathrm{b}}$ & $15.53 \pm 0.62^{\mathrm{a}}$ & $16.17 \pm 0.42^{\mathrm{a}}$ & 0.04 \\
$\quad$ Solid non fat & $9.09 \pm 0.41$ & $9.13 \pm 0.17$ & $9.32 \pm 0.25$ & 0.29 \\
Persistency of milk-production (\%) & & & \\
Somatic cell count & $89.35 \pm 17.37$ & $91.39 \pm 12.31$ & $79.62 \pm 25.41$ & \\
(105 cells/mL): & & & & \\
- Baseline & $9.54 \pm 5.72$ & $8.67 \pm 6.50$ & $10.93 \pm 7.16$ & \\
- After research & $12.67 \pm 7.78$ & $3.07 \pm 2.27$ & $7.60 \pm 3.80$ & 0.89 \\
\%Change & 11.64 & -28.74 & -8.41 & 0.90 \\
\hline
\end{tabular}

Note: Means in the same row with different superscripts differ significantly $(\mathrm{P}<0.05)$. T0 (control diet= basal diet without fermented coffee husk supplementation), T1 (basal diet with $6 \%$ fermented coffee husk supplementation), and T2 (basal diet supplemented with $6 \%$ fermented coffee husk soaked for an hour in $3 \%$ crude palm oil). 
cell count. This result was consistent with the results reported by Wasser (2002) who found that consumption of mushroom could improve health condition.

\section{CONCLUSION}

The result of the current study confirmed the utilization of fermented coffee husk as feed supplement in ruminant diets. Fermented coffee husk could be used as ruminant feed supplement without any negative effect on digestibility and milk production. Biodegradation of coffee husk with Pleurotus ostreatus increased its nutritional value. The positive effects on udder health could be expected from including fermented coffee husk in diets.

\section{ACKNOWLEDGEMENT}

This work was supported by research fund from The Higher Education Directorate of Education Ministry through HIBAH BERSAING with research agreement No. 2011/UN30.10.06.01/HK/2012/h30.10/p1/2011 on date March $2^{\text {nd }} 2012$.

\section{REFERENCES}

AOAC. 2005. Official Method of Analysis. $15^{\text {th }}$ edition. Association of Official Analytical Chemist. Washington, DC. USA.

Badarina, I., D. Evvyernie, T. Toharmat, E. N. Herliyana, \& L. K. Darusman. 2013. Nutritive value of coffee husk fermented with Pleurotus ostreatus as ruminant feed. Med. Pet. 36:5863. http://dx.doi.org/10.5398/medpet.2013.36.1.58

Chan, G. C. F., W. F. Chan, \& D. M. Sze. 2009. The effect of $\beta$ glucan on human immune and cancer cells. J. Hematol. Oncol. 2:1-11. http://dx.doi.org/10.1186/1756-8722-2-25

Chen, J. \& R. Seviour. 2007. Medicinal importance of fungal $\beta-$ (1-3), (1-6) - glucans. Mycol. Res. 3:635-652. http://dx.doi. org/10.1016/j.mycres.2007.02.011

Fan, L., A.T. Soccol, A. Pandey, L. P. S. Vandenberghe, \& C. R. Soccol. 2006. Effect of caffeine and tannins on cultivation and fructification of Pleurotus on coffee husks. Braz. J. Microbiol. 37:420-424. http://dx.doi.org/10.1590/S151783822006000400003

Fazaeli, H., H. Mahmodzadeh, J. B. Liang, A. Azizi, \& A. Osman. 2002. Effect of fungal treated wheat straw on the diet of lactating cows. Asian-Aust. J. Anim. Sci. 15:1573-1578. http://dx.doi.org/10.5713/ajas.2002.1573

Fazaeli, H., H. Mahmodzadeh, A. Azizi, Z. A. Jelan, J. B. Liang, Y. Rouzbehan, \& A. Osman. 2004. Nutritive value of wheat straw treated with Pleurotus fungi. Asian-Aust. J. Anim. Sci. 17:1681-1688. http://dx.doi.org/10.5713/ajas.2004.1681

Goering, H. K. \& P. J. Van Soest. 1970. Forage Fiber Analysis. Agriculture Handbook No. 379. Agricultural Research Service, USDA, Washington DC. p 20.

Gouvea, B. M., C. Torres, A. S. Franca, L. S. Oliveira, \& E. S. Oliveira. 2009. Feasibility of ethanol production from coffee husks. Biotechnol. Lett. 31: 1315-9. http://dx.doi. org/10.1007/s10529-009-0023-4

Harborne, J. B. 1989. General Procedures and Measurement of Total Phenolics. In: J. B. Harborne (Ed). Methods in Plant Biochemistry. Volume I. Plant Phenolics. Academic Press, London.

Hassim, H. A., M. Laurenco, Y. M. Goh, J. J. P. Baars, \& V. Fievez. 2012. Rumen degradation of oil palm fronds is improved through pre-digestion with white rot fungi but not through supplementation with yeast or enzymes. Can. J. Anim. Sci. 92:79-87. http://dx.doi.org/10.4141/cjas2011-097

Herliyana, E. N., D. Nandika, Achmad, L. I. Sudirman, \& A. B. Witarto. 2008. Biodegradation of sengon-wood sawdust substrate by Pleurotus group fungi from Bogor. J. Tropical Wood Science and Technology 6:75-84.

Min, B. R., S. P. Hart, T. Sahlu, \& L. D. Satter. 2005. The effect of diets on milk production and composition, and on lactation curves in pastured dairy goats. J. Dairy. Sci. 88:26042615. http://dx.doi.org/10.3168/jds.S0022-0302(05)72937-4

Murthy, P. S. \& K. Mannomani. 2008. Bioconversion of cofffee industry wastes with white rot fungus Pleurotus Florida. Res. J. Environ. Sci. 2:145-150. http://dx.doi.org/10.3923/ rjes.2008.145.150

Novak, M. \& V. Vetvicka. 2009. Glucans as biological response modifiers. Endocrine, Metabolic \& Immune DisordersDrug Targets. 9:67-75. http://dx.doi.org/10.2174/18715300 9787582423

NRC. 2001. Nutrient Requirement of Dairy Cattle. Revised Ed. National Academic Press, Washington DC.

Okano, K., S. Fukui, R. Kitao, \& T. Usagawa. 2007. Effect of cultural length of Pleurotus eryngii grown on sugarcane bagasse on in vitro digestibility and chemical composition. Anim. Feed. Sci. Technol. 136: 240-247. http://dx.doi. org/10.1016/j.anifeedsci.2006.08.024

Parani, K. \& M. Eyini. 2012. Biodegradation of coffee pulp waste by different fungal associations. Bioscience Discovery 3: 222-228

Patel, Y., R. Naraian, \& V. K. Singh. 2012. Medicinal properties of Pleurotus species (Oyster mushroom): A review. World Journal of Fungal and Plant Biology 3:01-12.

Periasamy, K. \& K. Natarajan. 2004. Role of lignocellulosic enzymes during basidiomata production by Pleurotus djamor var roseas. Indian Journal of Biotechnology 3: 577-583

Sanchez, C. 2009. Lignocellulosic residues: Biodegradation and bioconversion by fungi. Research review paper. Biotechnol. Adv. 27:185-194. http://dx.doi.org/10.1016/ j.biotechadv.2008.11.001

Sharif, A. \& G. Muhammad. 2008. Somatic cell count as an indicator of udder heallth status under modern dairy production: A Review. Pakistan Vet. J. 28:194-200.

Sharma, N., N. K. Singh, \& M. S. Bhadwal. 2011. Relationship of somatic cell count and mastitis: An Overview. AsiaAust. J. Anim. Sci. 24:429-438. http://dx.doi.org/10.5713/ ajas.2011.10233

Shearer, J. K. \& Jr. B. Harris. 2008. Mastitis in Dairy Goats. IFAS Extention. University of Florida, USA.

Steel, R. G. D. \& J. H. Torrie. 2003. Principles and Procedures of Statistics. 2ed. Mc. Graw-Hill Book Co. Inc., New York.

Sudarwanto, M. \& E. Sudarnika. 2008. The relationship between $\mathrm{pH}$ value of milk and the somatic cell count as a parameter of sub-clinical mastitis detection. Med. Pet. 31: 107-113.

Tabrizi, M. H. R., H. Sadeghipanah, M. Chamami, Y. Ebrahim-Nejad, \& H. Fazaeli. 2011. In-vitro gas production of wheat grain flour coated with different fat types and levels. African J. Biotechnol. 10:7710-7716.

Wasser, S. P. 2002. Medicinal mushrooms as a source of antitumor and immunomodulating polysaccharides (minireview). Appl. Microbiol. Biotechnol. 60: 258-274. http:// dx.doi.org/10.1007/s00253-002-1076-7

Wong, K. H., C. K. M. Lai, \& P. C. K. Cheung. 2011. Immunomodulatory activities of mushroom sclerotial polysaccharides. Food Hydrocolloid. 25:150-158. http://dx.doi. org/10.1016/j.foodhyd.2010.04.008 